LAURENCE STERNE AND THE ARGUMENT ABOUT DESIGN 


\section{LAURENCE STERNE AND THE ARGUMENT ABOUT DESIGN}

Mark Loveridge 
(C) Mark Loveridge 1982

Softcover reprint of the hardcover 1st edition 1982

All rights reserved. No part of this publication may be reproduced or transmitted, in any form or by any means, without permission

$\begin{array}{ccccccccc}10 & 9 & 8 & 7 & 6 & 5 & 4 & 3 & \\ 04 & 03 & 02 & 01 & 00 & 99 & 98 & 97 & 96\end{array}$

Published by

THE MACMILLAN PRESS LTD

London and Basingstoke

Companies and representatives

throughout the world

ISBN 978-1-349-05602-6 ISBN 978-1-349-05600-2 (eBook)

DOI 10.1007/978-1-349-05600-2 
To Olive and Basil 


\section{Contents}

Preface ix

Acknowledgements $\quad$ x

Abbreviations $\quad$ xi

Introduction 1

1 Sterne and the Form of the Novel 6

Sterne and The English Novel $\quad 6$

Sterne and The Russian Novel 18

Sterne and The German Novel 24

2 Plot and Character in Tristram Shandy 30

Plot and Conspiracy $\quad 30$

The Conflict Between Character and System in Volume I of Tristram Shandy 40

Gravity as Plot and Hobby-Horse 58

3 Sterne and the Scientific Study of Man 71

4 Breaking Patterns: Analogy and Proportion 94 Ar.alogy as Modelling $\quad 94$ Tristram's Related Arts 106

The Heart of the Work: A Treatment of
Proportion in Volume III

5 Sterne and Locke $\quad 129$

Uncle Toby, John Locke and the Search

for Truth

The Author's Preface

6 Sympathy and Sentiment 151

The Sermon and its Contexts 158 
viii

Contents

7 A Sentimental Journey 167

Text

173

Background

193

Notes and References

210

Select Bibliography

228

Index

243 


\section{Preface}

A number of studies have been of particular help in the construction of this book. Martin Battestin's article 'Tom Jones: The Argument of Design' suggested a banner under which various aspects of the work could be brought together. The most useful general studies were John Traugott's Tristram Shandy's World: Sterne's Philosophical Rhetoric, R. F. Brissenden's Virtue in Distress, the chapter on Sterne in A. D. McKillop's The Early Masters of English Fiction, and Gabriel Josipovici's The World and the Book. Victor Erlich's Russian Formalism: History-Doctrine provided the starting-point for the first chapter, and helped to show me an approach to the other materials of the book. The other work which helped to suggest an approach was Ronald Paulson's Theme and Structure in Swift's 'A Tale of a Tub'. The chapter on A Sentimental Journey has benefited from having to disagree with Arthur Cash's Sterne's Comedy of Moral Sentiments: The Ethical Dimension of the Journey.

Rather late in the day, I read Eric Rothstein's Systems of Order and Enquiry in Later Eighteenth-Century Fiction, and found it highly interesting on the subjects of system and analogy, and on their prevalence in eighteenth-century thought and art. It also has a stimulating chapter on Sterne's methods of construction and control in Tristram Shandy.

In the endnotes and bibliography, provenance of sources is London where not otherwise specified.

I should like to record my gratitude for the constant encouragement and stimulation offered by $\mathrm{Dr}$ Howard Erskine-Hill of Pembroke College, Cambridge, who supervised the work for the thesis from which this study is adapted. And to Kate, who typed it.

January 1980

Mark Loveridge 


\section{Acknowledgements}

The author and publishers wish to thank the following, who have kindly given permission for the use of copyright material: Oxford University Press for extracts from An Essay Concerning Human Understanding by John Locke edited by P. H. Nidditch (1975); and Ram's Horn Music for two lines from Idiot Wind by Bob Dylan, copyright (C) 1974, 1975, all rights reserved. 


\section{Abbreviations}

TS Laurence Sterne, The Life and Opinions of Tristram Shandy, Gentleman (1760-67), ed. J. A. Work (New York: Odyssey Press, 1940), 4th printing 1960.

SJ Laurence Sterne, $A$ Sentimental Journey through France and Italy (1768), ed. Ian Jack (London: OUP, 1968).

ELH Journal of English Literary History

PMLA Publications of the Modern Language Association of America

$M L Q \quad$ Modern Language Quarterly

EC Essays in Criticism

PQ Philological Quarterly 